\title{
Financial Policy and Corporate Performance: An Empirical Analysis of Nigerian Listed Companies
}

\author{
Rafiu Oyesola SALAWU \\ Department of Management and Accounting, Obafemi Awolowo University, Ile-Ife, Nigeria \\ Tel: 234-803-379-5887Ｅ-mail: rsalawu@oauife.edu.ng \\ Taiwo Olufemi ASAOLU \\ Department of Management and Accounting, Obafemi Awolowo University, Ile-Ife, Nigeria \\ Tel: 234-803-721-6060_E-mail: tasaolu@yahoo.co.uk \\ Dauda Olalekan YINUSA \\ Department of Economics, Obafemi Awolowo University, Ile-Ife, Nigeria \\ Tel: 234-803-517-1663_E-mail: yinusaolalekan@yahoo.com
}

$\begin{array}{lc}\text { Received: November 4, } 2011 & \text { Accepted: December 16, } 2011 \quad \text { Published: April 1, } 2012 \\ \text { doi:10.5539/ijef.v4n4p175 } & \text { URL: http://dx.doi.org/10.5539/ijef.v4n4p175 }\end{array}$

\begin{abstract}
This study investigates the effects of financial policy and firm specific characteristics on corporate performance. Panel data covering a period from 1990 to 2006 for 70 firms were analyzed. Pooled OLS, Fixed Effect Model and Generalized Method of Moment panel model were employed in the estimation and data were sourced from the annual report and financial statement of the sampled firms. The estimation of the dynamic panel-data results show that long-term debts, tangibility, corporate tax rate, dividend policy, financial and stock market development were all positively related with firms' performance. Furthermore, the positive relationship between stock market development and ROA suggest that as stock market develops, various investment opportunities are opened to firms. Therefore, there is need to monitor the performance of these variables in order to stabilize and enhance performance of listed firms in Nigeria. In addition, the result shows that growth, size and foreign direct investment are negatively related with firms' performance (ROA). In addition, the result indicates that higher income variability increases the risk that a firm may not be able to cover its interest payment, leading to higher expected costs of financial distress. This may leads to reduce their profitability. The results of the study generally support existing literature on the impact of financial policy on corporate performance.
\end{abstract}

Keywords: Firms’ performance, GMM, Financial policy

\section{Introduction}

The Federal Military Government of Nigeria in 1987 deregulated the interest rates as part of the Structural Adjustment Programme (SAP) policy package. The official position then was that the interest rate liberalization would among other things enhance the provision of sufficient funds for investors, especially manufacturers, who were considered to be the prime agents, and by implication promoters of economic growth. Moreover, the institutional set-up within which firms were operated had undergone substantial transformation since the mid 1980s and early 1990 s.

Since 1987, the financial liberalization in Nigeria has changed the operating environment of firms by giving more flexibility to the financial managers in choosing the capital structure of the firm. As such, firms will be able to adjust their capital accumulation behaviour depending upon business risk and investment opportunities observed by capital market. The financial deregulation reinstates market mechanism and enforces evolutionary argument that most efficient firms are able to stay in market because they have access to the capital market while the less efficient ones exit from industry.

The performance of publicly listed companies in Nigeria has been unsatisfactory despite several policy reforms introduced over the years. There is an argument that corporate firms carrying heavy short-term debt burdens (risk) 
can pose a threat to firms' performance and the economy. This has implication on the capital choice and performance of listed companies in Nigeria. Yet, there is paucity of studies in this area which necessitates this study. Therefore, the objective of this study is to investigate the effect of capital structure and firms' specific characteristics on the performance of listed companies. The rest of this paper is organized as follows: Section two briefly examines the literature review. Section three presents method of analysis. Section fours centre on the discussion of the results, while section five is devoted to conclusion and recommendations.

\section{Literature Review}

Bevan and Danbolt (2001). using the fixed effects panel estimation, find that profitability appears to be negatively correlated with the level of gearing. Devic and Krstic (2001). in their study of Poland firms, find profitability to be a significant determinant of corporate financing patterns when book values of equity are used in the computation of leverage. According to them, the inverse relationship between profitability and leverage supports the Pecking order theory of capital structure. Hovakimian, Opler and Titman (2001) report in their study that even though high profitability is associated with low leverage, it is also associated with a higher probability of issuing debt vi-a-vis issuing equity, which is consistent with dynamic tradeoff models.

Fama and French (2002) agree that the negative effects of profitability on leverage is consistent with the pecking order model, but also find that there is an offsetting response of leverage to changes in earnings, implying that the profitability effects are in part due to transitory changes in the target. Mira (2002). using the ordinary OLS finds that profitability has a negative coefficient which corroborates the pecking order theory. Panno (2003). Mesquita and Lara (2003) using the ordinary least square examine the influence of the capital structure of 70 Brazillian companies regarding profitability. They discovered that profitability presents a positive correlation with short-term debt and equity, and an inverse correlation with long-term debt. Strebulaev (2003) uses a calibrated dynamic trade-off model with adjustment costs to simulate firms' capital structure paths. He argues that the simulated cross-sectional samples leverage is inversely related to profitability. Graud et al (2003) in their study of 106 Swiss companies using both static and dynamic tests find that lagged profitability has a positive impact on leverage, which confirms the prediction of a short term pecking order behaviour towards the target ratio

Pandey (2004) finds a saucer-shaped relation between capital structure and profitability, due to the interplay of agency costs, costs of external financing and debt tax shield. According to Haas and Peeters (2004). in their study of central and eastern European firms, profitability and age of firms are the most robust determinants of their capital structure targets, whereas profitability decreases firms' leverage targets. Salawu (2007). reports in his study that profitability has positive impact on leverage of large firms in Nigeria, confirming that the tax advantage of debt financing has nonetheless its relevance in Nigerian large firms. Akhigbe and Madura (2008) measure the long-term valuation effects following dividend initiations and omissions. They find that firms initiating dividends experience favorable long-term share price performance. Conversely, firms omitting dividends experience unfavorable long-term share price performance. The long-term valuation effects resulting from dividend initiations are more favorable for firms that are smaller, that over invest, and that had relatively poor performance prior to the initiations. The long-term effects resulting from dividend omissions are more unfavorable for large firms and for firms experiencing relatively large dividend omissions.

Bokpin and Abor (2009) analyze the effects of financial policy on corporate performance of emerging market firms. Their study employs fixed effects panel model estimation technique. The results indicate that capital structure has negative effects on return on assets and return on equity but is positively related with market-to-book value ratio. Dividend payout is also positively related with return on assets and return on equity.

Early and recent empirical studies focused on the relationship between profitability and capital structure. However, the causal relationship between profitability and capital structure has not been empirically resolved. The prior researches generally did not take into account the possibility of reverse causation from performance to capital structure. If a firm's performance affects the choice of capital structure, then failures to take this reverse causality into account may result in simultaneous equations bias. That is, regressions of firm performance on a measure of leverage may confound the effects of capital structure on performance with the effects of performance on capital structure.

\section{Data and Methodology}

The study employed secondary annual panel data for the period 1990 to 2006. Seventy (70) out of the one hundred (100) non-financial firms listed on the Nigerian Stock Exchange (NSE) were purposively selected for analysis. The sample of companies cut across fourteen (15) sectors according to the Nigerian Stock Exchange classification. Firm specific characteristics data were sourced from Annual Report and Accounts of the sample firms and annual publications of the Nigerian Stock Exchange such as fact books. The macroeconomics variables (inflation, foreign 
direct investment, trade openness) were sourced from various editions of the Central Bank of Nigeria's statistical bulletin, Annual Report and Statement of Account and Economic and Financial Review as well as the Abstract of the Federal Bureau of Statistics. Descriptive statistic and econometric techniques of analysis were employed.

\subsection{Model Specification}

To achieve a complete dynamic specification allowing for possible AR-process and to examine adjustment cost effect, the lagged dependent variable is incorporated into equation (1).

$$
\mathrm{y}_{\mathrm{it}}=\alpha-\beta \mathrm{y}_{\mathrm{i}(\mathrm{t}-1)}+\Sigma \mathrm{X}_{\mathrm{it}}+\Sigma K_{i t}+\eta_{\mathrm{i}}+\lambda_{\mathrm{it}}+\mathrm{U}_{\mathrm{it}}
$$

with $\mathrm{i}=1 \ldots ., \mathrm{N}$ and $\mathrm{t}=1, \ldots, \mathrm{T}_{\mathrm{i}}$

where :

$y_{i t}-$ the performance of firm $i$ in year $t$

$\mathrm{X}_{\mathrm{it}}-$ is a vector of firm specific characteristics variables

$K_{i t}$ - is a vector of macroeconomics variables

$\eta_{i}$ - individual effects i.e. firm-specific effect

$\lambda_{t}-$ time specific effects (e.g. interest rates, demand shocks). which are

common to all firms and can change overtime.

$\mathrm{U}_{\mathrm{it}}$ - the time-varying disturbance term is serially uncorrelated with mean zero and variance.

The chosen performance measure is Return on Assets (ROA). Thus, specifying the models explicitly we have:

$$
\begin{aligned}
& R O A_{i t}=\omega_{0}+\omega_{1} \mathrm{LEV} 1+\omega_{2} \mathrm{LEV} 2+\omega_{3} T A N G_{i t}+\omega_{4} \text { GROW } W_{i t}+\omega_{5} S I Z_{i t}+\omega_{6} \text { CTR }_{i t}+\omega_{7} \\
& E P O W_{i t}+\omega_{8} V O L T_{i t}+\omega_{9} I N V+\omega_{11} D I V_{i t}+\omega_{12} T O P_{i t}+\omega_{13} I N F_{i t}+\omega_{14} F D I_{i t}+\omega_{15} \\
& \text { BMKTS }_{i t}+\omega_{16} \text { STKA }_{i t}+\eta_{i}+\lambda_{i t}+U_{i t}
\end{aligned}
$$

Where:

ROA $=$ Return on Assets $=$ EBIT $/$ Total Assets

LEV1 $=$ Total debt $/$ Total Assets

LEV2 $=$ Long-term debt/Total Assets

TANG $=$ Tangibility $=$ Fixed Asset $/$ Total Assets

GROW $=$ Growth Opportunity $=$ TA in Year $(\mathrm{t}) / \mathrm{TA}$ in Year $(\mathrm{t}-1)$

SIZ $=$ Size of the firm $=$ the natural logarithm of total sales

$\mathrm{CRT}=$ Corporate tax rate $=$ Tax paid/Operating income

VOLT $=$ Volatility $=$ standard deviation of EBIT $/$ EBIT

$\mathrm{DIV}=$ Dividend $=$ Dividend paid/Book value of equity

EPOW $=$ Earning Power $=\log$ of EBIT

$\mathrm{TOP}=$ Trade Openness $=$ Export + Import $/$ GDP

$\mathrm{INF}=$ Inflation $=$ the percentage change in consumer price index

FDI $=$ Foreign direct investment $=$ real investment $/$ GDP

BMKTS $=$ Bank market size $=$ total domestic credit divided $/$ GDP.

STKA $=$ Stock market activity $=$ total value traded/GDP

$\eta_{\mathrm{i}}-$ individual effects i.e. firm-specific effect

$\lambda_{t}-$ time specific effects (e.g. interest rates, demand shocks). which are

common to all firms and can change overtime.

$\mathrm{U}_{\mathrm{it}}-$ the time-varying disturbance term is serially uncorrelated with 
mean zero and variance.

\section{Results and Discussion}

An examination of descriptive statistics for dependent and explanatory variables reveals the following observations. Firm performance (ROA) has experienced a low growth rate with the average growth rate standing at $13.26 \%$. The disparity in profitability ranged from 0.0000 minimum values for some firms to a maximum value of 2.90 . This presents a great disparity between firms in performance. The mean value of 0.1326 reveals that companies under review will prefer more debts and less equity. This is justified by the mean value of total debt/total assets (LEV1) of $68.99 \%$, which mean that equity account for the remaining $31.01 \%$. As far as the long-term debt/total asset is concerned, the means value is very low $(0.13356)$.

Considering the standard deviation (S.D) which measures the level of variation or degree of dispersion of the variables from their mean reveals that firm performance (ROA) is relatively stable an S.D of $15.17 \%$ compared with other variables. The least volatile/most stable variable is trade openness (TOP) $5.33 \%$ and followed by foreign direct investment (FDI) $19 \%$.

In order to determine the effect of the selected variables on the firms' performance, three functional forms of estimation techniques were used; the pooled ordinary least squares (OLS). the fixed effect model (FEM) and generalized moment method (GMM) estimation. Table 2 presents the results of the pooled OLS, fixed effects and GMM estimation for firm performance (ROA). The analysis of the firm performance under pooled OLS reveals a series of coefficients that are significant at one percent (1\%) level and ten percent $(10 \%)$ level. The results of the fixed effects in Table 2 for the firms' performance element suggest that the explanatory power of the regressions is higher. The adjusted $\mathrm{R}^{2}$ is satisfactory in all the cases. The adjusted $\mathrm{R}^{2}$ is 0.3433 under pooled OLS, while it is 0.4416 under fixed effect model. The F-values are also significant in all the models. Both fixed and random effects specifications of the model were estimated and subsequently, the Hausman specification test was conducted to determine the appropriate specification. The report of the Hausman test is presented in Table 2. The test statistics is significant at $1 \%$, suggesting that the fixed effects model is preferred over the random effects. Thus, the null hypothesis was rejected and the alternative hypothesis is accepted.

The results indicate statistically significant (at 1\%) positive relationship between return on asset (ROA) and capital structure (LEV1) under the three estimation techniques, with marginal contribution of $0.0931,0.0892$ and 0.0427 respectively. It implies that, a one-percentage increase in firms' capital structure (total debt/total assets-LEV1) will lead to $4.27 \%$ (GMM estimation) increases in firms' performance i.e. profitability. Also, under fixed effect model and GMM estimation, firms' performance is positively related to long-term debt ratio, with 0.0186 and 0.2316 coefficients respectively. This positive relationship could also represent growth option to the firm and may require external financing. As firms diversify, their productive assets ought to be financed and one of the options opened to them is the use of debt, hence this positive relationship. This result justified the mean value of total debts (68.99\%) and the relationship between LEV1 and profitability (PROF) which is consistent with trade-off theory.

A positive relationship exist between the previous firm performance $\{\operatorname{ROA}(-1)\}$ and the current firms' performance (ROA). The value of coefficient is 2.4615 and is significant at $1 \%$ level. This indicates that with a change by one percent in the previous firms' performance; there will be a corresponding change of about $246.15 \%$ in the level of current firms' performance.

Growth opportunities (GROW) and sizes of the firm (SIZ) have negative relationship with firms' performance; however, the coefficients are significant at $1 \%$ level. This indicates that growth and size have no significant positive impact on firm performance. This suggests that firms in Nigeria will prefer external financing to internal financing. There is a positive but not significant relationship between dividend policy (DIV) and firm performance under fixed effect model and GMM estimation. This positive relationship implies that dividend policy is taken with the view of increasing firm performance. This confirms the views of Black (1976) and Easterbrook (1984) that dividend policy could help save companies from the problem of overinvestment. This is because; they reduce the amount of free cash flow available to the firm. Payment of dividend may push management to the capital market to raise finance.

In Table 2, GMM estimation reveals that tangibility, corporate tax shield and earning power are positively related to return on assets, however, only tangibility is not significant. An increase in any of these variables will improve firms' performance.

The estimated coefficients of trade openness (TOP) in the Table 2 are negative under the three models and only significant at $1 \%$ level for fixed effect model and GMM estimation. Trade openness has not impacted positively on the firms' performance in Nigeria. An important policy implication is that the benefit of trade openness may vary from industry/sector to industry. If the quoted companies in Nigeria are to benefit from the globalization programme 
(trade openness). the trade openness policy is an indispensable tool. Trade policies that ensure increased globalization would stimulate firms' performance. Foreign direct investment (FDI) has negative relationship with corporate performance and significant at $1 \%$ level. Policies designed to increase FDI should not only be tailored to increasing the positive effects of FDI on firms' performance but also to ensuring that all the sectors have equal access to the benefits of trade openness.

Inflation (INF) exhibited positive relationship with corporate performance and significant at $5 \%$ level under GMM estimation. The result suggests that firms experiencing high inflation tend to exhibit high return on assets. The coefficients under the models $0.0003,0.0003$ and 0.0002 respectively which indicate that with a change in the level of inflation by one percent, there will be a corresponding change of about $0.02 \%$ or $0.03 \%$ in the level of firms' performance. The impact of inflation on firms' performance is less than $1 \%$.

Furthermore, financial market development (BMKTS) is positively related to firms' performance and significant at $1 \%$ under GMM estimation. It indicates that one percent increase in financial market development will lead to $0.14 \%$ increase in return on assets. The impact is very low. Moreover, the coefficients of stock market development (STKA) under fixed effect model and GMM estimation are significant at $1 \%$ level. The implication of this is that an increase in stock development by $1 \%$ indicates a growth in corporate performance to about an approximately $3 \%$ to $6 \%$. Also, the results indicate that as stock market develops, various investment opportunities and financing choices are opened to firms and this will increase corporate performance. Fama (1981) and Barro (1989) have argued that there is a link between stock market activity and investment and as well forms an important component of changes in market value of capital.

\section{Conclusion}

Foreign direct investment (FDI) has negative relationship with corporate performance and significant at $1 \%$ level. Policies designed to increase FDI should not only be tailored toward increasing the positive effects of FDI on firms' performance but also to ensuring that all the sectors have equal access to the benefits of trade openness. Trade openness (TOP) has not impacted positively on the firms' performance in Nigeria.

The results show significant positive relationships between stock market developments (STKA) and the corporate performance. The results indicate that as stock market develops, various investment opportunities and financing choices are opened to firms and this will increase corporate performance. However, the impact of stock development and financial market development are at slow rate.

The estimation of the dynamic panel-data regression also suggest that long-term debts, tangibility, corporate tax rate, dividend policy, financial and stock market development were all positively related with firms' performance. Therefore, there is need to monitor the performance of these variables in order to stabilize and enhance performance of listed firms in Nigeria. On the other hands, growth, size and foreign direct investment are negatively related with firms' performance.

The following recommendations are made. There is the need for policy measures capable of increasing the fixed asset base of Nigerian companies. Companies in Nigeria should not only absorb the depreciation allowances but also, the net addition to the stock of fixed assets should be provided for. If the quoted companies in Nigeria are to benefit from the globalization programme, the trade openness policy is an indispensable tool. Trade policies that ensure increased globalization would stimulate firms' performance. The Nigerian government should encourage stock market development through appropriate regulatory policies to remove barriers to stock market operation and thus enhance its efficiency. Also, financial managers should endeavour to reinvest the profit generated for growth and expansion rather than consuming it.

\section{References}

Akhigbe, A., \& Madura, J. (2008). Dividend Policy and Corporate Performance. Journal of Business Finance \& Accounting, Vol. 23, Issue 9-10, pp. 1267-1287.

Arellano, M., \& Bond, S. (1991). Some Tests of Specification for Panel Data: Monte Carlo Evidence and an Application to Employment Equations. Review of Economic Studies, Vol. 58, pp. 297. http://dx.doi.org/10.2307/2297968

Bervan, A. A., \& Daubolt, J. (2001). Testing for Inconsistencies in the Estimation of UK Capital Structure Determinants, Working Paper 2001/4, Department of Accounting and Finance, University of Glasgow, Glasgow G $12 *$ LE.

Bokpin, G. A., \& Abor, J. (2009). Financial Policy and Corporate Performance: Evidence from Emerging Market Economies. African Finance Journal, Vol.11, No.1, pp.24-36 
Devic, A., \& Krstic, B. (2001). Comparatible Analysis of the Capital Structure Determinants in Polish and Hungarian Enterprises-Empirical Study Economies and Organisation, Vol. 1, No. 9, pp. 85 - 100.

Fama, E. F., \& French, K. R. (2002). Testing Tradeoff and Pecking Order Predictions about Dividends and Debt, Working Paper, University of Chicago and Sloan School of Management (MIT).

Panno, A. (2003). An Empirical Investigation on Determinants of Capital Structure: The UK and Italian Experience. Journal of Applied Financial Economics, Vol13 Pp 97 - 112. http://dx.doi.org/10.1080/09603100210100882

Mesquita, J. M. C., \& Lara J. E. (2003). Capital Structure and Profitability: The Porazilian Case, Center of Postgraduate Studies and Research, Federal University of the State of Minas Gerais.

Hovakimian, A., Opler, T., \& Titman, S. (2001). The Debt-Equity Choice. Journal of Financial and Quantitative Analysis, 36, 1-24.

Graud, P., Jani, E., Hoesli, M., \& Bender, A. (2003). The Capital Structure of Swiss Companies: an empirical analysis using dynamic panel data, Finance Research Seminar Paper, University of Geneva.

Pandey, I. M. (2004). Capital Structure, Prifitability and Market Structure: Evidence from Malaysia. Asia Pacific Journal of Economics and Business, Vol8, No2.

Haas, R., \& Peeters, M. (2004). The Dynamic Adjustment Towards Target Capital Structures of Firms in Transition Economies, Working paper no. 87, European Bank for Reconstruction and Development.

Salawu, R. O. (2009). Financial Risk, Capital Structure and the Performance Listed Companies in Nigeria (1990-2006). An Unpublished Ph.D Thesis submitted to the Department of Management and Accounting, Obafemi Awolowo University, Ile-Ife, Nigeria.

Table 1. Descriptive Statistics of Firms' Performance and other variables

\begin{tabular}{|l|l|l|l|l|l|l|l|}
\hline & Mean & Median & Maximum & Minimum & Std-Deviation & No. Of Observation & Cross Section \\
\hline Return on Assets ROA & 0.1326 & 0.1020 & 2.9035 & 0.0000 & 0.1517 & 1044 & 70 \\
\hline Total Liabilities/Total Asset & 0.6899 & 0.6607 & 6.2731 & -0.7094 & 0.4576 & 1044 & 70 \\
\hline Long-term Liabilities/Total Asset & 0.1335 & 0.0599 & 4.6576 & -0.2711 & 0.3029 & 1044 & 70 \\
\hline Volatility (VOLT) & 6.5046 & 1.0259 & 403.27 & 0.0121 & 27.4389 & 1044 & 70 \\
\hline Tangibility (TANG) & 0.3262 & 0.2974 & 0.9999 & 0.0006 & 0.1885 & 1044 & 70 \\
\hline Growth Opportunity (GROW) & 1.3908 & 1.1952 & 21.0650 & 0.0011 & 1.1403 & 1044 & 70 \\
\hline Size of the Firm (SIZ) & 6.0959 & 6.0603 & 8.4696 & 2.9269 & 0.8593 & 1044 & 70 \\
\hline Corporate Tax Rate (CTR) & 0.7209 & 0.2039 & 222.099 & -10.5921 & 7.4131 & 1044 & 70 \\
\hline Earning Power (EPOW) & 5.0388 & 5.0164 & 8.2576 & 2.1959 & 0.9016 & 1044 & 70 \\
\hline Income Variability (INV) & 7.0656 & 11.6355 & 1.4367 & 2.8051 & 4.1420 & 1044 & 70 \\
\hline Dividend Paid (DIV) & 56.2343 & 0.4298 & 15833.34 & 0.000267 & 711.0737 & 1044 & 70 \\
\hline Trade Openness (TOP) & 0.5857 & 0.5978 & 0.6664 & 0.5046 & 0.0533 & 1044 & 70 \\
\hline Inflation (INF) & 25.1608 & 14.0470 & 72.8120 & 4.7637 & 20.7694 & 1044 & 70 \\
\hline Foreign Direct Investment (FDI) & 0.3397 & 0.3059 & 0.5422 & 0.1605 & 0.1129 & 1044 & 70 \\
\hline Financial Market Development & 19.6057 & 19.6820 & 35.4950 & 9.0059 & 7.5043 & 1044 & 70 \\
\hline Stock Market Development & 0.3399 & 0.0794 & 1.9617 & 0.0017 & 0.5161 & 1044 & 70 \\
\hline
\end{tabular}


Table 2. Regression Model Estimate: Firm's Performance (ROA)

\begin{tabular}{|c|c|c|c|}
\hline & POOLED OLS RESULT & FIXED EFFECT RESULT & GMM RESULTS \\
\hline $\mathrm{C}$ & $\begin{array}{l}0.1345 \\
(1.2881) \\
\end{array}$ & $\begin{array}{l}0.0545 \\
(0.5444) \\
\end{array}$ & \\
\hline ROA (-1) & & & $\begin{array}{l}0.3243 \\
(2.4615)^{*}\end{array}$ \\
\hline LEV1 & $\begin{array}{l}0.0931 \\
(7.4749)^{*}\end{array}$ & $\begin{array}{l}0.0892 \\
(6.7205)^{*}\end{array}$ & $\begin{array}{l}0.0427 \\
(5.2068)^{*}\end{array}$ \\
\hline LEV2 & $\begin{array}{l}-0.0045 \\
(-0.2308) \\
\end{array}$ & $\begin{array}{l}0.0186 \\
(0.8655) \\
\end{array}$ & $\begin{array}{l}0.2316 \\
(6.5734)^{*}\end{array}$ \\
\hline VOLT & $\begin{array}{l}0.0002 \\
(1.0820) \\
\end{array}$ & $\begin{array}{l}-0.0002 \\
(-1.3251) \\
\end{array}$ & $\begin{array}{l}0.0002 \\
(0.9355) \\
\end{array}$ \\
\hline TANG & $\begin{array}{l}-0.055 \\
(-2.5845)^{*}\end{array}$ & $\begin{array}{l}0.0547 \\
(1.8346)^{* * *}\end{array}$ & $\begin{array}{l}0.0455 \\
(1.5067)\end{array}$ \\
\hline GROW & $\begin{array}{l}-0.0062 \\
(-1.8143)^{* * *}\end{array}$ & $\begin{array}{l}-0.0048 \\
(-1.4630) \\
\end{array}$ & $\begin{array}{l}-0.0116 \\
(-6.1383)^{*}\end{array}$ \\
\hline SIZ & $\begin{array}{l}-0.1118 \\
(-10.9418)^{*}\end{array}$ & $\begin{array}{l}-0.0693 \\
(-5.439)^{*}\end{array}$ & $\begin{array}{l}-0.0559 \\
(-8.7623)^{*}\end{array}$ \\
\hline CTR & $\begin{array}{l}0.0025 \\
(4.7172)^{*}\end{array}$ & $\begin{array}{l}0.0014 \\
(2.6916)^{*}\end{array}$ & $\begin{array}{l}0.0035 \\
(6.8109)^{*}\end{array}$ \\
\hline EPOW & $\begin{array}{l}0.1581 \\
(8.3094)^{*} \\
\end{array}$ & $\begin{array}{l}0.1551 \\
(14.1729)^{*}\end{array}$ & $\begin{array}{l}0.1524 \\
(5.2790)^{*}\end{array}$ \\
\hline INV & $\begin{array}{l}-7.71 \mathrm{E}-10 \\
(-2.6389)^{*}\end{array}$ & $\begin{array}{l}4.09 \mathrm{E}-10 \\
(0.6317)\end{array}$ & $\begin{array}{l}-2.56 \mathrm{E}-05 \\
(0.8811) \\
\end{array}$ \\
\hline DIV & $\begin{array}{l}-2.85 \mathrm{E}-06 \\
(-0.5251)\end{array}$ & $\begin{array}{l}3.15 \mathrm{E}-06 \\
(0.5032)\end{array}$ & $\begin{array}{l}2.17 \mathrm{E}-05 \\
(0.8811) \\
\end{array}$ \\
\hline TOP & $\begin{array}{l}-0.2791 \\
(-1.5846)\end{array}$ & $\begin{array}{l}-0.5968 \\
(-3.3622)^{*}\end{array}$ & $\begin{array}{l}-0.3728 \\
(-5.5348)^{*}\end{array}$ \\
\hline INF & $\begin{array}{l}0.0003 \\
(1.2822) \\
\end{array}$ & $\begin{array}{l}0.0003 \\
(1.0814) \\
\end{array}$ & $\begin{array}{l}0.0002 \\
(2.0296)^{* *}\end{array}$ \\
\hline FDI & $\begin{array}{l}-0.0877 \\
(-1.2183)\end{array}$ & $\begin{array}{l}-0.1579 \\
(-2.3082)^{*}\end{array}$ & $\begin{array}{l}-0.1240 \\
(-5.4419)^{*}\end{array}$ \\
\hline BMKTS & $\begin{array}{l}0.0008 \\
(0.7196) \\
\end{array}$ & $\begin{array}{l}0.0009 \\
(0.8737)\end{array}$ & $\begin{array}{l}0.0014 \\
(4.7715)^{*}\end{array}$ \\
\hline STKA & $\begin{array}{l}0.0537 \\
(3.5323) \\
\end{array}$ & $\begin{array}{l}0.0600 \\
(4.1982)^{*}\end{array}$ & $\begin{array}{l}0.0292 \\
(5.1441)^{*}\end{array}$ \\
\hline Adjusted $\mathrm{R}^{2}$ & 0.3433 & 0.4416 & \\
\hline F-Statistic & $\begin{array}{l}37.349 \\
(0.0000) \\
\end{array}$ & $\begin{array}{l}10.8206 \\
(0.0000) \\
\end{array}$ & \\
\hline D-Watson Stat. & 0.41 & 0.49 & \\
\hline Hausman Test & & $\begin{array}{l}3.6237 \\
(0.0000)\end{array}$ & \\
\hline J-Statistic & & & 58.416 \\
\hline Instrument Rank & & & 70.0000 \\
\hline No. of Observation & 1044 & 1044 & 909 \\
\hline Cross Section Included & 70 & 70 & 70 \\
\hline
\end{tabular}

NOTE: LEV 1 refers to total liabilities/total assets, LEV 2 refers to long-term liabilities/total assets, Volatility (VOLT) is defined as standard deviation of EBIT/Earning before interest and tax. Income variability (INV) is standard deviation of turnover, tangibility (TANG) is defined as fixed assets/total assets. Firms' performance (ROA) refers to earning before interest and tax/total assets. Growth prospect (GROW) refers to the ratio of total assets in year t to total assets in year $t$-1. Size of the firm (SIZ) is the natural logarithm of sales. Corporate tax rate (CTR) is tax paid to Operating income. Non-debt tax shield (NDTS) is defined as the ratio of depreciation to total assets, while divided policy (DIV) is measured as dividend paid/book value of equity. Earning Power (EPOW) is natural log of EBIT. Trade Openness (TOP) is Export plus import/Gross Domestic Product, Inflation is measured by the percentage change in consumer price index. Foreign Direct Investment is defined as real investment/GDP, while financial market development (BMKTS) is total domestic credit divided by GDP. Stock market development (STKA) is defined as total value traded divided GDP. Numbers in parentheses appearing below coefficients are t-values. *,**and ***indicates coefficients is significant at the 1,5 and 10 percent levels respectively. 